\title{
Occurrence of Seed Coat Mottling in Soybean Plants Inoculated with Bean pod mottle virus and Soybean mosaic virus
}

\author{
H. A. Hobbs, Department of Crop Sciences; G. L. Hartman, United States Department of Agriculture-Agricultural \\ Research Service (USDA-ARS) and Department of Crop Sciences; Y. Wang, C. B. Hill, R. L. Bernard, and \\ W. L. Pedersen, Department of Crop Sciences; and L. L. Domier, USDA-ARS and Department of Crop Sciences, \\ University of Illinois at Urbana-Champaign, Urbana 61801
}

\begin{abstract}
Hobbs, H. A., Hartman, G. L., Wang, Y., Hill, C. B., Bernard, R. L., Pedersen, W. L., and Domier, L. L. 2003. Occurrence of seed coat mottling in soybean plants inoculated with Bean pod mottle virus and Soybean mosaic virus. Plant Dis. 87:1333-1336.

Soybean seed coat mottling often has been a problematic symptom for soybean growers and the soybean industry. The percentages of seed in eight soybean lines with seed coat mottling were evaluated at harvest after inoculating plants during the growing season with Bean pod mottle virus (BPMV), Soybean mosaic virus (SMV), and both viruses inside an insect-proof cage in the field. Results from experiments conducted over 2 years indicated that plants infected with BPMV and SMV, alone or in combination, produced seed coat mottling, whereas noninoculated plants produced little or no mottled seed. BPMV and SMV inoculated on the same plants did not always result in higher percentages of mottled seed compared with BPMV or SMV alone. There was significant virus, line, and virus-line interaction for seed coat mottling. The nonseed-coat-mottling gene ( $\mathrm{Im}$ ) in Williams isoline L77-5632 provided limited, if any, protection against mottling caused by SMV and none against BPMV. The Peanut mottle virus resistance gene Rpv1 in Williams isoline L85-2308 did not give any protection against mottling caused by SMV, whereas the SMV resistance gene Rsv1 in Williams isoline L78-379 and the resistance gene or genes in the small-seeded line L97-946 gave high levels of protection against mottling caused by SMV. The correlations ( $r=0.77$ for year 2000 and $r=0.89$ for year 2001) between virus infection of the parent plant and seed coat mottling were significant $(P=0.01)$, indicating that virus infection of plants caused seed coat mottling.
\end{abstract}

Incidence of soybean (Glycine max (L.) Merrill) seed coat mottling has increased in recent years in the midwestern United States $(8,23)$. Symptoms of soybean seed coat mottling include dark streaks or other patterns that radiate from the hilum and cause hilum bleeding. In other cases, the mottling is more generalized over the seed coat. The color (buff, brown, or black) of the mottling is controlled by genes that control the color of the hilum. Seed mottling is particularly important in food grade soybean, where dark pigment in the seed

Corresponding author: G. L. Hartman

E-mail: ghartman@uiuc.edu

Financial support was provided by the Illinois Soybean Check-off Board and North Central Soybean Research Board.

Trade and manufacturers names are necessary to report factually on available data; however, the USDA neither guarantees nor warrants the standard of the product, and the use of the name by the USDA implies no approval of the product to the exclusion of others that may also be suitable.

Accepted for publication 3 June 2003.

Publication no. D-2003-0904-01R

This article is in the public domain and not copyrightable. It may be freely reprinted with customary crediting of the source. The American Phytopathological Society, 2003. coat can reduce consumer acceptance. For example, soybean used for the Japanese soy food "natto" must be uniformly yellow in seed coat color or it will be rejected by buyers. Recently, some small-seeded lines specifically developed for the natto market have been unmarketable in some years due to the frequency of seed coat mottling ( $R$. L. Bernard, unpublished).

The role of Soybean mosaic virus (SMV) in seed coat mottling has been firmly established $(4,13,16,17,19,21)$ whereas the role of Bean pod mottle virus (BPMV) in seed coat mottling has been less clear, with some reports stating that BPMV causes mottling $(8,9,14,23)$ and other reports stating that it does not $(16,18,19)$. Mixed virus infection (SMV and BPMV) was reported to produce higher percentages of seed coat mottling than that caused by SMV alone $(16,18,19)$. The roles of other factors in seed coat mottling have not been confirmed with certainty, such as certain abiotic factors (15).

The objective of this study was to determine if the infection of soybean plants by BPMV and SMV alone or in combination would affect seed coat mottling in eight soybean entries.

\section{MATERIALS AND METHODS}

Soybean lines. Seed of eight soybean lines (four from a breeding program for small-seeded soybean for natto production, and the cv. Williams and three of its isolines) were planted at the University of Illinois Crop Science Research and Education Center (CSREC) South Farm, Urbana, IL in 2000 and 2001. The natto types, L951805 (line 1) and L98-7220 (line 2), were selected because they exhibited little or no seed coat mottling, whereas natto types L97-946 (line 3) and L98-7625 (line 4) were selected because they exhibited heavy seed coat mottling when grown at the CSREC South Farm (Table 1). Cv. Williams was used as a susceptible check for seed coat mottling. Three Williams isolines (2), three single gene transfers to Williams (BC-5 derived), were used, including L77-5632 with the nonseed coat mottling gene Im (7) from cv. Hawkeye, L78-379 with an SMV resistance gene Rsv1 (12) from PI 96983, and L85-2308 with a Peanut mottle virus (PMV) resistance gene Rpvl $(1,3)$ from cv. Dorman. Germplasm with this last gene previously has shown low levels of mottling in the field at CSREC South Farm (R. L. Bernard, unpublished).

Virus isolates. An SMV G5 (5) isolate originally was obtained from J. Hill, Iowa State University, maintained by continuous greenhouse transfer using mechanical inoculation as described for the field cage experiments (see below), and stored long term in freeze-dried leaves. The BPMV 98 isolate was collected from infected soybean on the CSREC South Farm and was maintained using the same methods.

Field cage experiments. During the summer of 2000 and 2001, experiments were conducted in a field cage on the CSREC South Farm (Urbana, IL). The 13by-19-m cage had a galvanized steel frame and was covered with a 32-mesh cover to exclude insect vectors.

Single row plots, $0.3 \mathrm{~m}$ in length and $0.76 \mathrm{~m}$ between rows, were hand sown with 10 seed per row. Treatments were (i) SMV inoculation, (ii) BPMV inoculation, (iii) mixed inoculation, and (iv) noninoculated check (control). Plots were arranged in a split-plot design with virus treatments as main plots and cultivars as subplots with three complete blocks.

Virus extracts from infected leaves of Williams 82 plants maintained in the greenhouse were prepared by grinding infected leaves with sterilized pestles and 
mortars in chilled $0.025 \mathrm{M} \mathrm{KPO}_{4}$ buffer, $\mathrm{pH} 7.1$, plus $0.01 \mathrm{M}$ sodium sulfite. Leaf surfaces were dusted with Carborundum (320 grit) and pestles were used to apply inoculum to the youngest 1 to 2 leaves during mechanical inoculation. SMV G5 inoculations were done 2 weeks after planting (first trifoliolate) and BPMV was inoculated a week later.

Virus symptoms were observed 18 and 28 days after inoculation. Data recorded were based on visual appearance of leaf mosaic, leaf and stem necrosis, and plant stunting.

At the R6 growth stage (full green pod development), individual plants were labeled and the youngest leaf or green pod was sampled from each plant and tested for the presence of BPMV and SMV using double-antibody sandwich (DAS) enzymelinked immunosorbent assay (ELISA) (6) using Agdia antibodies and ELISA protocol (Agdia, Inc., Elkhart, IN). Sample wells with absorbance values (at 405-nm wavelength) more than twice those of healthy soybean control wells in each plate were considered positive.

When plants reached maturity, they were individually harvested, wrapped in burlap, and air dried. Seed were obtained from plants using a stationary threshing machine.

Seed coat mottling. Evaluations of seed coat mottling for seed from each individual plant in the 2000 and 2001 cage experiments were done by visual estimation of the percentage of harvested seed with mottling symptoms. Seed were examined carefully to detect small numbers of mottled seed or inconspicuous types of mottling. An individual seed was considered mottled when any mottling was observed, regardless of the extent of seed coat coverage. The estimates of two examiners were recorded and the mean between the two calculated for each replication. Statistical analyses of seed coat mottling data were performed with the aid of JMP (version 5; SAS Institute, Cary, NC). Correlations between virus infection of parent plants $(+$ or -$)$ and seed coat mottling (+ or -$)$ were calculated (Microsoft Excel:Mac v.X).

\section{RESULTS}

Field observations. Lines inoculated with BPMV developed moderate to severe foliar mosaic symptoms, whereas most lines inoculated with SMV developed severe foliar mosaic symptoms. Most lines inoculated with both viruses showed a synergistic effect of the virus combination, developing severe mosaic symptoms, necrosis, and stunting. Exceptions to these generalizations were with the SMV-resistant lines, line 3 and Williams-Rsv1, which were symptomless when inoculated with SMV, and developed moderate to severe mosaic symptoms when inoculated with both viruses, similar to symptoms when inoculated with BPMV alone. Except for a few scattered plants, the noninoculated control plants remained symptomless throughout the course of the experiments (see noninoculated control plant section below).

The small-seeded lines with a light-colored hilum had buff (brownish) seed coat mottling that was sometimes extensive, covering most of the seed surface. It was difficult to clearly associate some of this type of mottling with the hilum, although some less-extensive streaking appeared to emanate from the hilum in some seed. In contrast, Williams and its isolines with a darker hilum had seed coat mottling with black streaks always appearing to emanate from the hilum, or enlarged areas of black pigment around the hilum. There were no clear differences in seed mottling appearance induced by BPMV and SMV.

There was a significant $(P<0.0001)$ line, virus, and interaction of the two for seed coat mottling in both years (Table 2). Line 4 in 2000 and line 1 in 2001 were excluded from the statistical analyses because of mortality or lack of seed production of line 4 and ineffective inoculation of SMV in line 1.

BPMV-inoculated plants. Leaves and green pod samples from all the inoculated entries were ELISA-positive, and all lines had seed coat mottling. Seed coat mottling percentages for the inoculated plants were higher in 2001 than in 2000 in all lines except line 3 , in which mottling decreased (Figs. 1 and 2). Seed coat mottling percentages increased in Williams and its isolines from 2000 to 2001 (Figs. 1 and 2). The SMV resistance in line 3 and the Rsvl gene in Williams-Rsvl did not provide protection against seed coat mottling caused by BPMV (Figs. 1 and 2).

The non-seed-coat-mottling gene $\mathrm{Im}$ in Williams-Im, the PMV resistance gene Rpv1 in Williams-Rpv1, and the SMV resistance gene $R s v 1$ in Williams-Rsvl did not reduce seed coat mottling caused by BPMV when compared with Williams (Figs. 1 and 2).

Comparisons between lines 1, 2, 3, and 4 inoculated with BPMV showed that there were significant differences $(P<0.001)$ between lines 1 and 2 (means $=6$ and $5 \%$, respectively) and line 3 (mean $=56 \%$ ) in the 2000 cage experiment (Fig. 1), and that significant $(P<0.001)$ differences between line $2($ mean $=9 \%)$ and line 4 (mean = $54 \%$ ) occurred in 2001 (Fig. 2). Data from line 1 was not used in analysis of variance in 2001 because of insufficient numbers of SMV-infected plants in the SMV and mixed infection treatment; however, the mottling percentage was $8 \%$ in the BPMV treatment, similar to that of line 2 .

SMV-inoculated plants. Leaves and green pod samples from all the entries were ELISA-positive for SMV, except for samples from line 3 and Williams-Rsv1, which were ELISA-negative. SMV caused seed coat mottling in the six susceptible lines but not in the SMV-resistant entries in both 2000 and 2001 (Figs. 1 and 2). The seed coat mottling percentage varied depending on the entry and the year. In both

Table 2. Statistical analysis of the effects of Bean pod mottle virus, Soybean mosaic virus, and mixed infection on seed coat mottling of soybean lines in 2000 and 2001 cage experiments

\begin{tabular}{|c|c|c|c|c|c|}
\hline \multirow[b]{2}{*}{ Source } & \multirow[b]{2}{*}{ df } & \multicolumn{2}{|c|}{ Year 2000} & \multicolumn{2}{|c|}{ Year 2001} \\
\hline & & MS & Prob $>F$ & MS & Prob $>F$ \\
\hline Line & 6 & 554.59 & 0.0009 & $1,594.85$ & $<0.0001$ \\
\hline Virus & 3 & $5,153.43$ & $<0.0001$ & $9,946.98$ & $<0.0001$ \\
\hline Block & 2 & 321.60 & 0.0772 & 25.90 & 0.6675 \\
\hline Virus $\times$ line & 18 & 574.79 & $<0.0001$ & 446.95 & $<0.0001$ \\
\hline Block $\times$ virus & 6 & 79.48 & 0.6848 & 59.86 & 0.3923 \\
\hline
\end{tabular}

Table 1. Soybean lines used in seed coat mottling cage experiments in 2000 and 2001

\begin{tabular}{lll}
\hline Line & Name & \multicolumn{1}{c}{ Characteristics related to seed coat mottling } \\
\hline 1 & L95-1805 & $1999: 1,1 ; 2000: 3,1^{\mathrm{a}}$ \\
2 & L98-7220 & $1999: 2,1 ; 2000: 2,2^{\mathrm{a}}$ \\
3 & L97-946 & $1999: 7,6 ; 2000: 6,4^{\mathrm{a}}$ \\
4 & L98-7625 & $1999: 8,5 ; 2000: 9,8^{\mathrm{a}}$ \\
Williams & Williams & U.S. commercial cultivar, susceptible to mottling \\
Williams-Im & L77-5632 & Im non-seed-coat-mottling gene from cv. Hawkeye \\
Williams-Rsv1 & L78-379 & Rsv1 Soybean mosaic virus resistance gene from PI 96983 (introduced from Korea in 1932) \\
Williams-Rpv1 & L85-2308 & Rpv1 Peanut mottle virus resistance gene from cv. Dorman \\
\hline
\end{tabular}

a Rating for two fields in both 1999 and 2000 where 1 is the lowest seed mottle rating and 9 is the highest based on a scale estimating percent seed coat coverage by mottling (R. L. Bernard, unpublished). 
years, seed coat mottling percentages of lines 1, 2, 4, and Williams, Williams-Im, and Williams-Rpvl were significantly higher $(P<0.001)$ than those of the SMVresistant line 3 and Williams-Rsvl (Figs. 1 and 2).

The non-seed-coat-mottling gene $\mathrm{Im}$ in Williams-Im and the PMV resistance gene $R p v 1$ in Williams-Rpvl provided limited if any protection against seed mottling caused by SMV, because the frequency of mottling was similar to Williams in both years (Figs. 1 and 2). Seed coat mottling induced by SMV in lines 1, 2, 3, and 4 in 2000 and 2001 in the cage did not agree with the results of field mottling ratings (Table 1). For example, line 2 had over $30 \%$ seed mottling in 2000 and 2001, whereas the field mottling rating was low; and line 3 had $1 \%$ or less seed mottling in 2000 and 2001, but had a high field mottling rating (Table 1; Figs. 1 and 2).

BPMV- and SMV-inoculated plants. Seed coat mottling percentages were only significantly $(P=0.05)$ higher in BPMV and SMV doubly infected plants than in both BPMV and SMV singly infected plants for Williams in 2000 and WilliamsIm in 2001 (Figs. 1 and 2). The SMV-resistant line 3 and Williams-Rsv1 showed negligible seed coat mottling percentages when challenged with SMV alone; therefore, seed coat mottling of these two lines in the mixed infection treatment probably was caused by BPMV only. Line 3 had higher percentages of seed coat mottling with BPMV alone than with mixed infection in 2000.

Noninoculated control plants. Individual control plant samples from plants at full green pod stage (growth stage R6) tested by ELISA showed that $4 \%$ in 2000 and $7 \%$ in 2001 were infected with BPMV or SMV. Only the $96 \%$ (in 2000) and the 93\% (in 2001) ELISA-negative plants were used to calculate seed coat mottling percentages. From these ELISA-negative plants, seed coat mottling was very low, ranging from 0 to $0.2 \%$ in 2000 and 0 to $1.5 \%$ in 2001 (Figs. 1 and 2).

Correlations between seed coat mottling and virus infection. Seed coat mottling of seed from individual plants (+ or -) and virus infection of individual parent

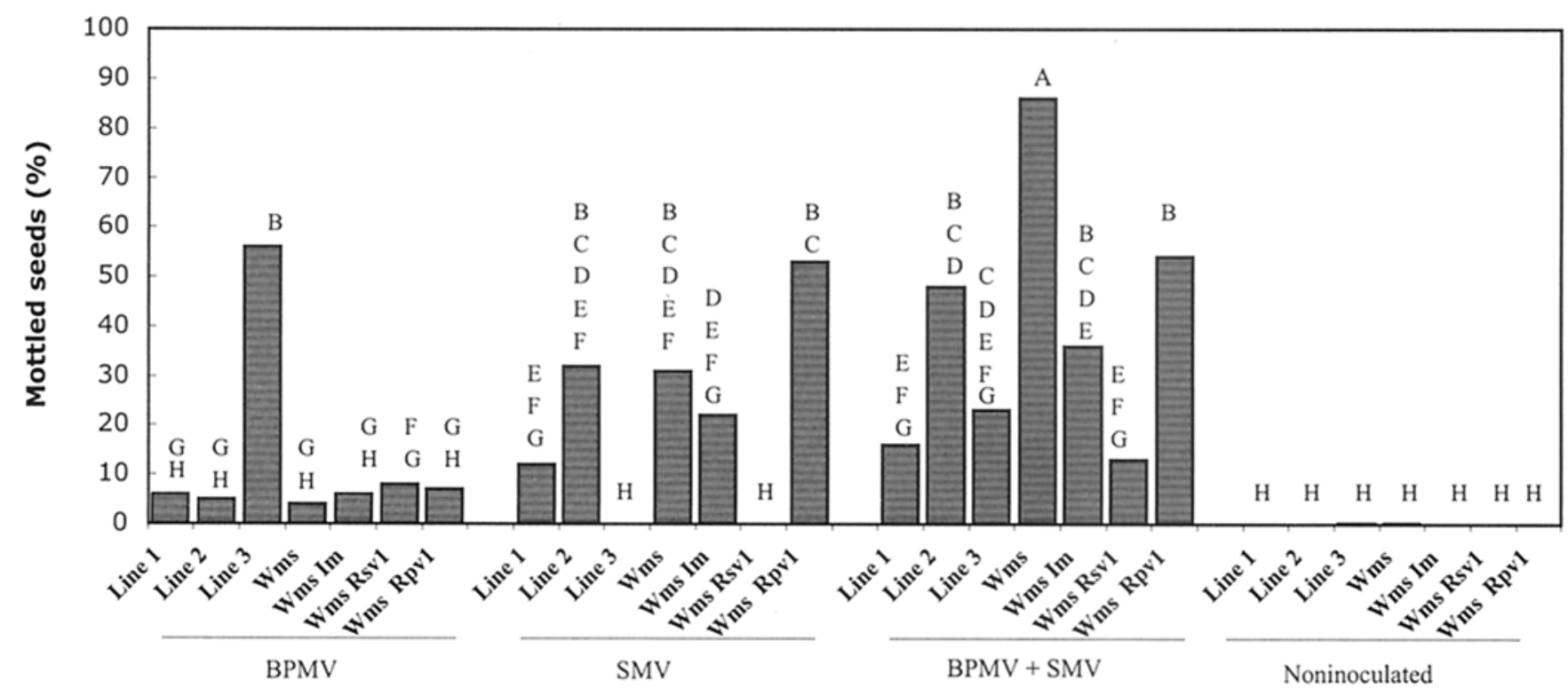

Fig. 1. Effect of Bean pod mottle virus (BPMV), Soybean mosaic virus (SMV), and mixed infection on percent mottled seed of soybean lines in 2000 field cage experiment. Values not followed by the same letter are significantly different $(P=0.05)$ by the least square means differences Student's $t$ test.

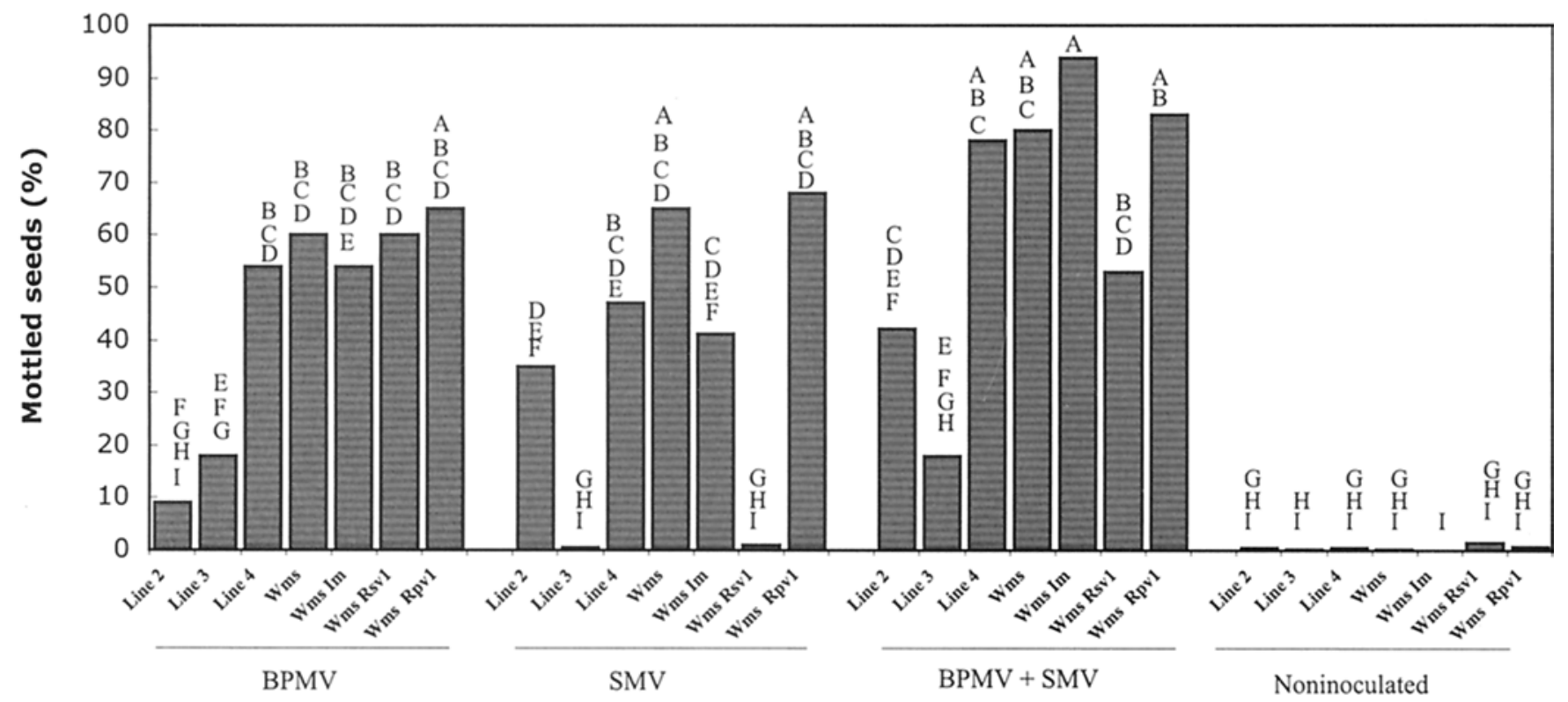

Fig. 2. Effect of Bean pod mottle virus (BPMV), Soybean mosaic virus (SMV), and mixed infection on percent mottled seed of soybean lines in 2001 field cage experiment. Values not followed by the same letter are significantly different $(P=0.05)$ by the least square means differences Student's $t$ test. 
plants $(+$ or -$)$ as determined by ELISA were significantly correlated $(P=0.01)$. Using data from 511 plants in 2000 and 762 plants in 2001 , the correlation coefficients for 2000 and 2001 were 0.77 and 0.89 , respectively.

\section{DISCUSSION}

Recent increases in the amount of soybean seed coat mottling in the midwestern United States probably are attributable to the widespread occurrence of BPMV. This widespread distribution of BPMV recently was reported for Nebraska and Iowa $(8,23)$. Based on surveys conducted by the authors (G. L. Hartman and L. L Domier, unpublished data), BPMV was widespread, whereas SMV was present in only a few locations in Illinois in 2000 and 2001. The levels of seed coat mottling observed in the field for lines 1 and 2 (low) and lines 3 and 4 (high) agree with the BPMV cage experiment results of 2000 and 2001. Line 3 was found to be resistant to SMV; therefore, it is likely that the field mottling from the initial assessments (R. L. Bernard, unpublished) was caused by BPMV. After further investigation, the pedigree of line 3 was found to include four potential donors of SMV resistance: PI 88788, Ogden, CNS, and Haberlandt (22).

The SMV resistance in line 3 and Williams-Rsv1 provided complete protection from mottling caused by SMV infection in the 2000 cage experiment. The low levels of mottling in these lines in the SMV treatment in 2001 (0.5 and $1 \%$, respectively) were similar to the mottling percentages in the noninoculated controls. All SMV-resistant plants used for seed mottling percentage calculation were ELISA-negative for SMV and for BPMV. All the noninoculated control plants used in seed mottling percentage calculation were ELISA-negative for SMV and for BPMV. There is a chance that BPMV or SMV transmission occurred by a few vectors that had entered the cage late in the season after sampling, and spread virus within the cage, but the infection was too late to be detected in samples (taken at growth stage R6) from the plants that produced mottled seed.

The Rpvl PMV resistance gene and the Im non-seed-coat-mottling gene in Williams-Rpv1 and Williams-Im did not provide significant protection against seed coat mottling caused by BPMV or SMV. Field observations at CSREC South Farm in previous years had indicated low levels of mottling for lines with Rpvl (R. L. Bernard, unpublished). Kennedy and Cooper (11) found that the Im gene present in cv. Merit protected seed from mottling caused by SMV, even though Merit was susceptible to SMV infection.
Although not every individual plant in this research that produced mottled seed tested ELISA-positive for presence of virus, and not every individual plant that tested ELISA-positive for virus produced mottled seed, the preponderance of data indicate that virus infection of the parent plant was responsible for seed coat mottling symptom development, as indicated by the significant correlations of individual plant ELISA reactions (+ or - ) and individual plant seed coat mottling (+ or - ). It is possible that, in certain other situations, environmental or other conditions may result in soybean seed coat discoloration, as reported with cold temperatures (15).

The results showed that some lines behaved inconsistently between 2000 and 2001 with respect to levels of mottling, particularly Williams and its isolines when infected with BPMV. Goodman et al. (10) found that a group of soybean lines selected for low levels of SMV-caused seed coat mottling one year had a high degree of mottling the next. The example given by Goodman et al. (10) of cv. Granger's SMV-caused seed mottling increasing from $6.5 \%$ one year to $61.1 \%$ the following year is very similar to the results with Williams and its isolines and BPMV-induced mottling in the current study. Some environmental factors may play a role in seed coat mottling expression, bringing about fluctuation in percentage of mottling from year to year (20).

The results of this study demonstrated that BPMV caused significant seed coat mottling. There is potential for seed coat mottling to become a greater problem in the future, because currently there are no commercial cultivars resistant to BPMV. Lines 1 and 2 used in these experiments maintained a low level of mottling in 1999 and 2000 field seasons, and in 2000 and 2001 cage experiments with BPMV infection. Identification of soybean lines such as lines 1 and 2 with several years of consistently low seed coat mottling incidence may be a useful partial control measure for seed coat mottling caused by BPMV.

\section{ACKNOWLEDGMENTS}

We thank R. L. Warsaw, L. P. Lau, and X. Zeng for technical assistance; and D. M. Eastburn for review of the manuscript.

\section{LITERATURE CITED}

1. Bays, D. C., Tolin, S. A., and Roane, C. W. 1986. Interactions of peanut mottle virus strains and soybean germplasm. Phytopathology 76:764-768.

2. Bernard, R. L., Nelson, R. L., and Creemens, C. R. 1991. USDA Soybean Genetic Collection: Isoline Collection. Soybean Genet. Newsl. 18:27-57.

3. Boerma, H. R., and Kuhn, C. W. 1975. Inheritance of resistance to peanut mottle virus in soybeans. Crop Sci. 16:533-534.
4. Bowers, G. R., Jr., and Goodman, R. M. 1991. Strain specificity of soybean mosaic virus seed transmission in soybean. Crop Sci. 31:1171-1174.

5. Cho, E. E., and Goodman, R. M. 1979. Strains of soybean mosaic virus: classification based on virulence in resistant soybean cultivars. Phytopathology 69:467-470.

6. Clark, M. F., and Adams, A. N. 1977. Characteristics of the microplate method of enzymelinked immunosorbent assay for the detection of plant viruses. J. Gen. Virol. 34:475-483.

7. Cooper, R. L. 1966. A major gene for resistance to seed coat mottling in soybeans. Crop Sci. 6:290-292.

8. Daniels, J. L., Munkvold, G. P., and McGee, D. C. 2001. Comparison of infected soybean seed and bean leaf beetles as inoculum sources for Bean pod mottle virus. (Abstr.) Phytopathology 91:S20.

9. Giesler, L. J., Ghabrial, S. A., Hunt, T. E., and Hill, J. H. 2002. Bean pod mottle virus, a threat to U.S. soybean production. Plant Dis. 86:1280-1289.

10. Goodman, R. M., Bowers, G. R., Jr., and Paschal, E. H. II. 1979. Identification of soybean germplasm lines and cultivars with low incidence of soybean mosaic virus transmission through seed. Crop Sci. 19:264-267.

11. Kennedy, B. W., and Cooper, R. L. 1967. Association of virus infection with mottling of soybean seed coats. Phytopathology 57:3537.

12. Kiihl, R. A. S., and Hartwig, E. E. 1979. Inheritance of reaction to soybean mosaic virus in soybeans. Crop Sci. 19:372-375.

13. Koning, G., TeKrony, D. M., and Ghabrial, S A. 2003. Soybean seedcoat mottling: Association with Soybean mosaic virus and Phomopsis spp. seed infection. Plant Dis. 87:413-417.

14. Lin, M. T., and Hill, J. H. 1983. Bean pod mottle virus: Occurrence in Nebraska and seed transmission in soybeans. Plant Dis. 67:230-233.

15. Morrison, M. J., Pietrzak, L. N., and Voldeng, H. D. 1998. Soybean seed coat discoloration in cool-season climates. Agron. J. 90:471-474.

16. Quiniones, S. S., Dunleavy, J. M., and Fisher, J. W. 1971. Performance of three soybean varieties inoculated with soybean mosaic virus and bean pod mottle virus. Crop Sci. 11:662664.

17. Ren, Q., Pfeiffer, T. W., and Ghabrial, S. A. 1997. Soybean mosaic virus incidence level and infection time: Interaction effects on soybean. Crop Sci. 37:1706-1711.

18. Ross, J. P. 1968. Effect of single and double infections of soybean mosaic and bean pod mottle viruses on soybean yield and seed characters. Plant Dis. Rep. 52:344-348.

19. Ross, J. P. 1969. Effect of time and sequence of inoculation of soybeans with soybean mosaic and bean pod mottle viruses on yield and seed characters. Phytopathology 59:1404-1408.

20. Ross, J. P. 1970. Effect of temperature on mottling of soybean seed caused by soybean mosaic virus. Phytopathology 60:1798-1800.

21. Tu, J. C. 1989. Effect of different strains of soybean mosaic virus on growth, maturity, yield, seed mottling and seed transmission in several soybean cultivars. J. Phytopathol. 126:231-236.

22. Wang, Y. 1996. Genetic resistance to and diversity of soybean mosaic virus. Ph. D. diss. University of Illinois, Urbana -Champaign.

23. Ziems, A. D., Giesler, L. J., Graef, G. L., and Lane, L. C. 2001. Effect of Bean pod mottle virus on soybean seed quality. (Abstr.) Phytopathology 91:S100. 